Archaeological Journal

\title{
Description of a Curious Leaden Font in the Church of Brookland, Kent
}

\section{Mr. Alexander Nesbitt}

To cite this article: Mr. Alexander Nesbitt (1849) Description of a Curious Leaden Font in the Church of Brookland, Kent, Archaeological Journal, 6:1, 159-164, DOI: 10.1080/00665983.1849.10850729

To link to this article: http://dx.doi.org/10.1080/00665983.1849.10850729

冓 Published online: 10 Jul 2014.

Submit your article to this journal $\sqsubset \pi$

Q View related articles $\longleftarrow$ 
Luck's Day, and bryng hym to chirche ;" 7 and another, dated October 7, 1687, at the beginning of the reign of James II., that there should be " $10 s$. allowed out of the company's stock for a sermon, and $2 s$. $6 d$. for the clerke," s which was afterwards increased, in 1722 , to $1 l$. for the minister, and $2 s$. $6 d$. for the clerk. ${ }^{9}$

J. WILSON.

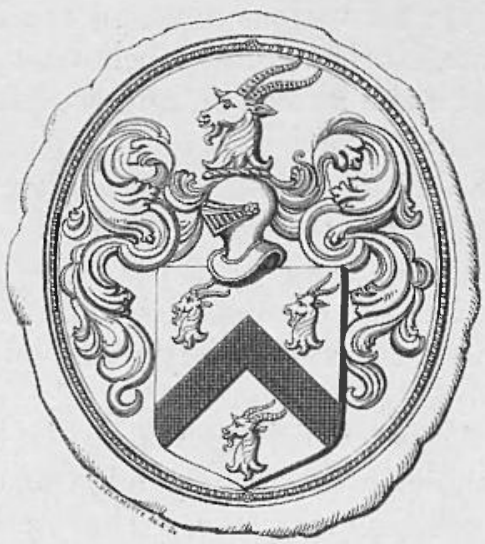

SEAL OF THE CORDWAINLRS OF OXFORD.

(To be continued.)

\section{DESCRIPTION OF A CURIOUS LEADEN FONT IN THE CHURCH OF BROOKLAND, KENT. \\ COMMUNICATED BY MR. ALEXANDER NESDITT. ${ }^{1}$}

IN the church of Brookland, a parish in Romney Marsh, in the county of Kent, on the road from Rye to Romney, a very interesting leaden font, of the Norman period, is preserved, of which no account or representation appears to have been published.

7 B. 9 ].

8 D. sub anno.

- E. sub anno. See also an order made on St. Luke's-day, 3 Eliz., B. 187 :-“M" M' that no man shail gyve to his servaunts everye frydaye more then butter or chese, for lack of the on, the other; and all other Imbrye (Ember days) for duble ffastss commandyd by the cluurche they shall have whyght bredde \& no kinde of other mete." And in the next page, "Itm hit ys agreyd that no Jurny man shall worke uppon Saturday at nyght by candle lyght or uppon Sunday in the mornyng openlye in the shoppe; uppon payne to forfett every suche tyme as he offendithe-xijd to the use of the occupacyon. And this article to be putt in executyon fourthw th ymmedyatly after this agrement," p. 188 .

1 The society is indebted to the kind liberality of Mr. Nesbitt, who obtained casts in plaster, at his expense, from the curious subjects in relief on this font. These casts, ten in number, were exhibited at the monthly meeting on March 2nd, and have been lindly presented by Mr. Nesbitt to the museum of the Institute. The font had been mentioned in Mr.Parker's valuable " Glossary of Gothic Arclitecture," but no representations of its curious details are there cited.-Ed. 
It will be seen by the accompanying illustrations, that the subjects represented are, in the upper arcade, the signs of the Zodiac; and, in the lower, occupations proper to the months. The names of the Zodiacal signs are placed on the upper, and those of the months on the lower arches.

Similar representations are frequently found in illuminated MSS., and calendars of various ages, on the Norman font at Burnham Deepdale, Norfolk, ${ }^{2}$ and I believe, upon some other fonts,-as also upon the misereres, and sculptured ornaments in our cathedrals and churches.

Several of the figures having been injured, and all very much clogged by paint, the casts, from which the accompanying woodcuts have been prepared, are not as distinct as might be wished, but the occupations intended to be represented, can, in most cases, be easily made out. The figures are as follows :-

January.-A figure, which seems to be represented as seated behind a table, in the right hand is an object, probably a drinking-horn, which looks like a short staff. What the object in the left hand may be meant for, I cannot determine. ${ }^{3}$ The head of this figure is very large, and has much the appearance of having two faces. Can an allusion to Janus be intended, represented as holding the augural staff?

This impersonation of the month is, however, quite in accordance with the authority of other middle-age representations, and exemplifies the quaint verses, found in the calendar, as given in some copies of the "Horæ, ad usum Sarum."

"In Jano claris calidisque cibis potiaris,

Atque decens potus post fercula sit tibi notus."

Zodiacal sign, AQUARIUS. A figure pouring water: the legend quite indistinct.

February.-A seated figure wearing a hood, and warming his hands over a fire. The projecting hood of the chimney is shown.

Zodiacal sign, two fishes.-PISCES. Of the legend, only PI . . . . can be clearly made out.

March.-A figure with a hood drawn over his head, mittens or cuffed gloves, such as are used in hedging, and what seems

\footnotetext{
a See the Memoir by Pegge, and the plate representing this font, Archaeologia, vol. $x$, p. 177 .

3 Brady (Clavis Calendaria, vol. i.) remarkis that the Anglo-Saxons, who were
}

much addicted to drinking, usually depicted January as a man seated at a table, and holding a goblet of ale to his moutl. Compare the figure drinking from a horn, on the Burnham font. 
NORMAN FONT OF LEAD AT BROOKLAND, KENT,
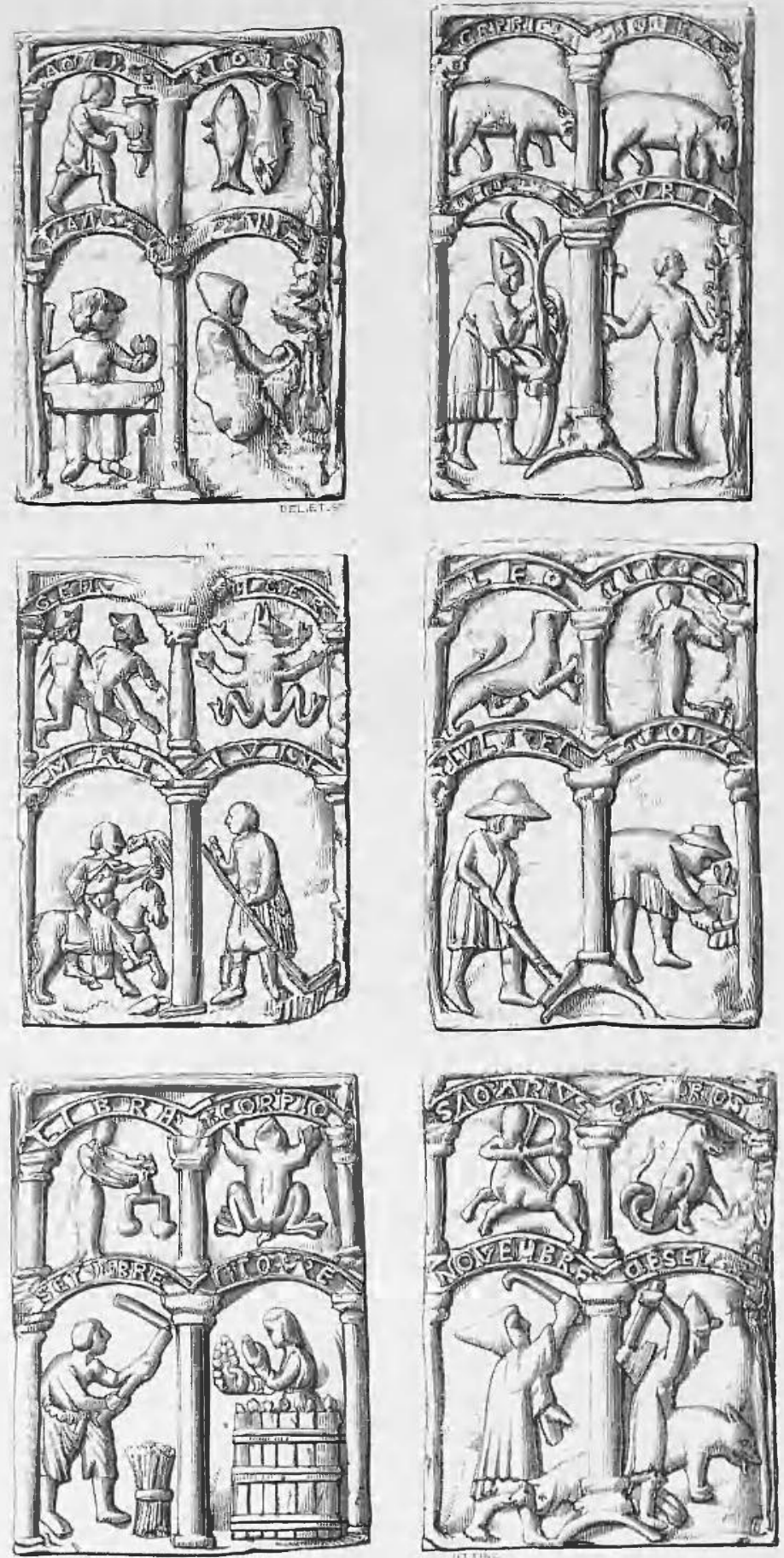
to be an overcoat; he is occupied in pruning $a^{\prime}$ shrub, probably a vine.

The Zodiacai sign represents a ram. The legend seems to read CAPRI . . . probably Capricornus by mistake for Aries.

April.-A standing figure, holding in each hand what is probably intended to represent a plant. This no doubt is to denote that this month is the proper season for planting or grafting. This figure is bareheaded, and dressed in a long robe. Above is the legend AVRIL.

Zodiacal sign, a bull.-TAURUS. The legend cannot be clearly read.

May.-A figure on horseback, with a hawk on his fist. Legend, MAI.

Zodiacal sign, two figures of boys.-GEMINI. GEM ... . may be read; the rest of the legend is obscure.

June.-A man mowing; the scythe seems very similar to the one at present in use. An object, possibly a whetstone, is seen hanging at his right leg. Brady gives the scythe as the ancient symbol of the month following. This figure is bareheaded, and wears a tunic, or short coat. Legend, JVIN.

Zodiacal sign, CANCER, represented by a figure with six legs, very unlike a crab. Of the legend . . NC . . may be made out.

July.-Called Hey-monat, by the Anglo-Saxons, - the Haytide.-A man working with what seems to be meant for a rake. He wears a sort of hat with wide brims, and a short coat. Legend, JVILLET.

Zodiacal sign, a lion, more like a leopard. Legend, LEO.

August.-A man reaping with a small sickle, and stooping. very much; he wears a similar hat to the previous figure. Legend, AOVT.

Zodiacal sign, a figure much defaced. Legend, VIRGO.

September.-A man thrashing. The head and upper part of the body bare, the lower covered apparently by short breeches. Legend, SEPTE'BRE.

Zodiacal sign, a figure holding a pair of scales. Legend, LIBRA.

October.-A figure standing in a tub, and holding a bunch of grapes; doubtless representing the treading grapes in a wine-press. Legend, OCTOBRE.

Zodiacal sign, a tolerably accurate figure of a frog. Legend, SCORPIO. 
November.-A figure wielding a crooked staff; his occupation seems to be indicated by a hog, whose head is seen near the ground. This figure wears a hood, and apparently an upper coat. It is probable that this may represent driving out swine to pannage in the woods, and the man wielding a hooked staff is occupied in beating down acorns, or "mast." 4 Legend, NOVEMBRE.

Zodiacal sign, a centaur with bow and arrow. Legend, SAGITARIVS.

December-A figure with an uplifted axe; an animal, probably intended for a hog, is represented in the lower part of the compartment. Legend, DESE . BR . Zodiacal sign, a very nondescript figure, with a beast's head and horns, a bird's body, wings, two legs, and a curled tail. Legend, CAPRIC .......

The twelve compartments not being sufficient for the required circumference of the font, eight of those described are repeated; the entire number forming the arcade being twenty. Above them is a line of hatched, and two lines of cable mouldings, and the font finishes with a plain lip, about an inch above the upper cable moulding. In two places, above the month of December, and between the months of June and July, these mouldings are interrupted by a square space, on which are small figures. These figures are five in number, and seem intended to represent the Resurrection of our Saviour. They are so much obscured by injuries and paint, that this may seem a questionable conjecture; but a very similar arrangement of the same subject often occurs in mediæval works, and one of the lower figures is represented as resting his head on his hand, as in sleep. It will be observed, that the names of the signs of the Zodiac are in Latin, whilst those of the months are in French, or Anglo-Norman. May it possibly be inferred from this circumstance that this font was fabricated in France ? ${ }^{5}$

4 Thus November is characterised in Regnault's "Horæ Sarum," 1524, "Michi pasco sues."

5 The observation here suggested by Mr. Nesbitt is not undeserving of attention, although no facts, corroborative of the supposition that these leaden fonts were of foreign manufacture, have been adduced. They are, indeed, rare at the present time in the northern parts of France (examples occur at Bourg Achard,
Normandy, and at Rouen, in the Museum.) It is remarkable that examples in England are almost exclusively of the Norman period. 'The following list of leaden fonts is probably far from complete, and notices of other examples will be acceptable :Llancaut and Tidenlıam, Gloucestershire (Archaeologia, xxix., pl. Ir1.) ; Frampton on Severn (Journ. Arcliaeol. Ass., ii. 184); Siston and Climbridge, (the last dated 1640), in the same county ; Walton- 
A comparison of various symbolical allusions to occupations of the months of the year, of which an interesting example has now been brought under the notice of the Institute, would present a curious subject of inquiry, in connexion, not less with the customs, than the agricultural routine of former times. These representations occur in great variety. Amongst the best examples of the Anglo-Saxon age may be cited the carefully-penned designs in the calendars, preserved in Cott. MSS., Tiberius, B. V., and Julius, A. VI. ; the former given in Strutt's "Manners and Customs," vol. i., plates X., XI., and XII. ; the latter in Mr. Henry Shaw's beautiful "Dresses and Decorations," vol. i., plates V. and VI. The subjects in this last are most delicately delineated, and their date may be assigned to the period immediately before the Conquest. The series of occupations is by no means identical with that exhibited on the Brookland font. The sculptures on the font at Burnham Deepdale, Norfolk, which were illustrated by Pegge in the Archaeologia, bear a much closer resemblance in the symbolical subjects represented, and are, indeed, nearly the same as those now exhibited from the leaden font in Kent. It will be not less interesting to compare the like series of personifications of the months, closely similar to those now given, but of a later age, preserved in the Harl. MS., 2331, and engraved by Strutt. ${ }^{6}$ These curious drawings are of the fifteenth century. In this series we find May portrayed with a falcon on his fist, as on the Brookland font, but he is not mounted. November wields an axe, his intention being indicated by an ox's head, which appears below, and December, represented on the leaden font as braining a porker, - the universal accompaniment of Christmas cheer,appears bearing the foaming jug and covered cup, whilst the corresponding compartment on the Burnham font exhibits a convivial assemblage.

Those readers who may be disposed to extend the comparison of the devices of this kind, so much in vogue in the times of our forefathers, will find much curious information in the Memoir by Pegge above cited, in the notices of the

on-the-Hill, Surrey; Chirton, Wilts ; Wareham, Dorset ; Childrey, Clewer, Wolstane, and Long Wittenlam, Berks; Dorchester, Clifton, and Warborough, Oxfordshire; Pitcombe, Somerset ; Edburton and Parhim, Sussex; Great Plumstead, Brundall, and two others in Norfolk.
Gough mentions, but erroneously, a leaden font at " Walmsford," Northamptonshire. The font at Wansford, given by Simpson, is of stone. $\Lambda$ stone font at Aslover, Dexbyshire, is ornamented with leaden figures.-Ev.

6 Manners and Customs, vol. ii, pl. 11 . 
ancient mode of representing the months given by Brady, and the observations by Gough, in his description of the sculptures on the remarkable Norman door-way of St. Margaret's Church, York, given in Carter's Specimens of Ancient Sculpture and Painting.

In concluding these notices of the Brookland font, the following verses, from an early edition of the Sarum Missal, may be cited as aptly characterising the twelve months, almost precisely in accordance with the representations now for the first time submitted to the notice of antiquaries.

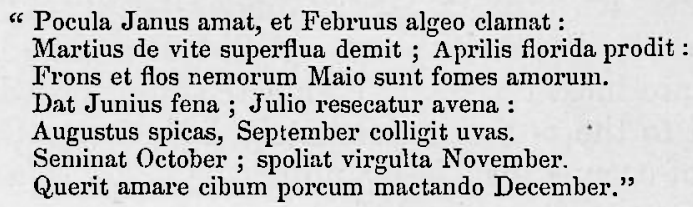

ON CERTAIN OBSCURE WORDS IN CHARTERS, RENTALS, ACCOUNTS, ETc., OF PROPERTY IN THE WEST OF ENGLAND.

(Continued.)

ADVOCATIO ; ADVOCARII ; ADVOCARIA. - In an account of the issues of Lidford Manor and Dartmoor Forest rendered by the ministers of Earl Edmund, 25 Edward I., I find among the "exitus forestæ" a sum of $8 d$. "de redditu cens' pro advocatione habendà."

The word "advocatio" appears in our law glossaries with no other meaning attached to it than that of an advowson. It is therefore natural to suppose that certain tenants of the forest at this time held the advowson of Lidford parish (which includes the forest) at an annual census or rent, and that these are the tenants called "censarii" 1 in later accounts. I am satisfied that this inference would be wrong, and that nothing is less likely than that the advowson should have been let to tenants at an annual rent of $8 d$.; especially to the class of persons whose payments are usually referred to under this head of "exitus forestæ."

Besides the meaning of advocatio already noticed, the word has another familiar to pleaders. Where a landlord justifies

1 The passage is so translated in Rowe's "Perambulation of Dartmoor," ed. 1848, p. 268 , by a gentleman, whose contribution to that work I feel myself peculiarly entitled to criticise without seruple. 